\title{
An Empirical Study of Supportive Communication Impacting Customer Satisfaction in Multinational Companys' Service Industry of Bangladesh
}

\author{
Bangladeş Hizmet Sektöründeki Çokuluslu Şirketlerde Müşteri Memnuniyetini Etkileyen \\ Destekleyici Iletişim Üzerine Görgül Bir Araştırma
}

A.K.M. Mominul Haque TALUKDER ${ }^{1}$

\begin{abstract}
In the accepted age of the "knowledge or information worker," information exchange and communication clarity are essential in the coordination of effort and control of organizational processes. Indeed, some researchers have reported that the bedrock of the effective implementation of any quality initiative (QI) within an organization involves the redefinition of both traditional boundaries and the communications channels that exist within an organization. The present research investigates various antecedents of supportive communication affecting customer satisfaction within employees. Result showed significant difference between managerial (MEs) and nonmanagerial (NMEs) employees in all the variables irrespective of active listening and defensiveness. The study reveals that MEs underscore on humanized leadership, teamwork, recognition vis-à-vis to NMEs to augment the level of customer satisfaction. Findings indicate that MEs are more assertive about long term implications of supportive communication than NMEs. The research also discloses NMEs' reluctance about supportive communication rather they are more interested in outright rewards and productivity. The findings recommend that incorporating these dimensions may render service organization with the potent to enhance customer satisfaction significantly.
\end{abstract}

Keywords: Emotional intelligence, leadership, teamwork, defensiveness, customer satisfaction.

\section{BACKGROUND}

Communications dynamics in organizations are necessarily multifaceted and intricate, reflecting the complex norms, values, climate, and goals of the organization and the environments in which the organization functions (Heath and Bryant, 1992). In functional terms, researchers in the area of communications in organizations have specifically investigated the processes of upward, downward, and sideways communications and communication maturity in organizations when evaluating onsite relational behavior (Marchington, 1995; Hurley, 1990). In the

\section{ÖZET}

"Bilgi veya bilgi işçisi" çağı olarak kabul edilen günümüzde, bilgi alışverişi ve net iletişim örgütsel süreçlerin kontrolü ve koordinasyonunda oldukça önemli hale gelmiştir. Bazı araştırmacılar bir örgütteki herhangi bir etkin kalite girişimi (QI) uygulamasının örgüt içerisindeki hem geleneksel sınırların hem de iletişim kanallarının yeniden tanımlanmasını kapsadığını ortaya koymuşlardır. Bu makale, çalışanlar arasında müşteri tatminini etkileyen destekleyici iletişimin önde gelen çeşitli unsurlarını araştırmaktadır. Bulgulara göre, yönetici kademesindeki (ME'ler) çalışanlar ve diğer çalışanlar (NME'ler) arasında aktif dinleme ve savunmadan bağımsız olarak tüm değişkenlerde önemli farklılıklar vardır. ME'ler müşteri tatminini arttırmak için insancıl liderliğin, takım çalışmasının ve NME'ler ile yüz yüze tanışıklığın altını çizmektedirler. Ayrıca ME'lerin diğer çalışanlara göre destekleyici iletişimin uzun dönemli etkileri konusunda daha iddialı oldukları ortaya çıkmıştır. Aynı zamanda NME'lerin destekleyici iletişim ile ilgili daha isteksiz oldukları, daha çok kesin ödüller ve verimlilikle ilgilendikleri görülmüştür. Sonuç olarak bulgular bu boyutları dikkate almanın hizmet işletmelerine müşteri tatminini önemli ölçüde arttırma olanağı vereceğini göstermektedir.

Anahtar Kelimeler: Duygusal zeka, liderlik, takım çalışması, savunmacilık, müşteri tatmini

applied setting, it is the appraisal of the existence and level of relational maturity between employees and management that indicates the level of true employee empowerment and collaboration in an organization (Buckley et al., 1998). A great deal of research supports the idea that positive interpersonal relationships are a key to creating positive energy in people's lives (Baker, 2000; Dutton, 2003). When people experience positive interactions-even if they are just temporary encounters-they are elevated, revitalized, and enlivened. Positive relationships create positive energy. Positive emotions such as joy, excitement, and interest are a product of positive 
relationship, and these emotions actually expand people's mental capacities. People's intellectual abilities are actually broadened, learn more efficiently, and make fewer mental errors when experiencing positive relationships (Fredrickson, 2001). Creativity and innovation, as well as ability of the system to adapt to change, are substantially higher when positive relationships characterize the workforce (Gittell, Cameron and Lim, 2006). As Schopenhauer (1964) implies, the desire for positive social relationships is one of the most fundamental and universal of human needs. People who lack positive relationships often experience loneliness, guilt, jealousy, depression, and anxiety (Leary, 1990), higher incidence of psychopathology (Bloom, White, and Asher, 1979), and reduced immune system functioning (Cacioppo, Hawkley, and Bernston, 2003). Given the strong need for social connection, coupled with the negative consequences associated with long-term social isolation, one might guess that people would respond to exclusion with increased motivation to build social bonds, perhaps especially with new (and possibly more promising) social partners. Arguably the most important skill in building and strengthening positive relationships is the ability to communicate with people in a way that enhances feelings of trust, openness, and support.

Strong communication skills that include insight into culture, diversity, nonverbal communication, and technology can help achieve goals and develop relationships that benefit organization. Although several studies have demonstrated the important role of the determinants of supportive communication on customers' satisfaction, no study has examined the interaction between the customer's satisfaction and perceived supportive communication and how these relationships affect customer satisfaction at the end. Till date nobody carried out an empirical study to see the cause and effect relationships among variables of supportive communication in the local context of Bangladesh. Hence, the study attempts to develop and quantitatively explore a conceptual model based on insights from various disciplines including organisational behavior, consumer behavior, psychology, and sociology to learn the relationship among factors of interpersonal relationships in service organization.

\section{LITERATURE REVIEW AND HYPOTHESES}

Supportive communication seeks to preserve or enhance a positive relationship between and another person while still addressing a problem, gi- ving negative feedback, or tackling a difficult issue (Whetten and Cameron, 2007). Outstanding customer service is almost impossible without supportive communication. Customer complaints and misunderstandings frequently require supportive communication skills to resolve. One important lesson that American managers have been taught by foreign competitors is that good relationships among employees, and between managers and employees, produce bottom-line advantages (Pfeffer, 1998). Hanson (1986) found that presence of good interpersonal relationships between managers and subordinates was three times more powerful in predicting profitability in $\mathbf{4 0}$ major corporations over a five year period than the four next most powerful variables-market share, capital intensity, firm size, and sales growth rate-combined.

More than anything else, communication is the key to getting workers to become more productive. That communication must be a two-way process rather than the traditional downward spiral of communication that is still seen in many organizations. More interaction also gives management more credibility with employees, which can be a tremendous asset in both good times and bad (Argenti, 1998). Many companies are still fearful, however, of sharing information with employees even though today's workers are much more educated than their counterparts of an earlier era and have less interest in simply climbing the corporate ladder. Enlightened managers know that the more information they provide to employees, the more likely these employees are to be highly motivated to do a better job, to advance in their positions, and to further the goals of the organization itself. Such enlightened thinking leads to an atmosphere of respect for all employees within the organization. This can be accomplished in many ways, but the best way to create this atmosphere is through the communication that managers have with employees, most of which should, ideally, come directly from one manager to the next, from supervisor to employee. As companies grow larger and more complex, however, this often becomes difficult, which is where the need for an employee communications function arises.

Batt and Moynihan (2004) report that the attitudes and motivation of workers are more likely to be important in interactive service jobs because satisfaction of dissatisfaction with work can more easily spill over into customer interactions, thereby directly affecting the quality of the service and the volume of sales. Where the behavior of the employees is said 
to play such a pivotal role in shaping customer's perceptions of the quality of the interaction it has been argued in that the empowerment of front-line workers will generate pro-social customer-oriented behavior which can inspire customer satisfaction and loyalty (Liao and Chuang, 2004). Batt (2002) believes that high-involvement practices are important for performance because they help employees develop the kind of firm-specific human capital-a detailed knowledge firm's products, customs and work processes-that assist them to interact more effectively with customers. Evidence indicates that satisfied employees increase customer satisfaction and loyalty (Koys, 2001). Satisfied employees are more likely to be friendly, upbeat, and responsive-which customers appreciate. And because satisfied employees are less prone to turnover, customers are more likely to encounter familiar faces and receive experienced service. These qualities build customer satisfaction and loyalty. The relation also seems to apply in reverse: Dissatisfied customers can increase an employee's job satisfaction. Employees who have regular contact with customers report that rude, thoughtless, or unreasonably demanding customers adversely affect the employee's job satisfaction (Bitner, 1994). There are lot of internal factors of supportive communication might influence customer satisfaction externally. But the present study has been confined to six determinants like Emotional Intelligence, Recognition, Active Listening, Leadership, Teamwork and Defensiveness and assumed that these are interrelated within the organizational context and would altogether affect customer satisfaction significantly. In the following sections different determinants of supportive communication affecting customer satisfaction have been spelled out.

\subsection{Emotional Intelligence (EI)}

Recent interest in the concept of Emotional Intelligence has emphasized the potential link between $\mathrm{El}$ and customer satisfaction, both as a criterion for selection (Barlow and Maul, 2000) and a development tool as a means of improving service quality and reducing the stress associated with emotional labor (Spector et al., 1988). In particular, emotional recognition, empathy and the control and management of negative emotions are considered to be key skills that individuals can develop through El training (Slaski and Cartwright, 2002). Furthermore, it is suggested that such initiatives can create a positive organizational climate for service (Schneider et al., 1998). Emotional intelligence is the ability to diagnose, recognize, control, and respond appropriately our own emotions as well as emotions of others. Emotional intelligent people are less likely to blow up, lose control, less likely to experience debilitating depression and anxiety, and more likely to manage own emotional states than those with less emotional intelligence. Empirical findings have found the ability model of emotional intelligence to be directly associated with a wide range of important work-related outcomes, including decision making and negotiation (Mueller and Curhan, 2006) and leadership (Leban and Zulauf, 2004). These abilities may also be indirectly related to other important work-related criteria, as they seem to influence an individual's capacity to form effective social relations (Lopes, Salovey, and Straus, 2003) and are linked to aspects of psychological well being (Brackett et al., 2006). One study at PepsiCo found that company units headed by managers with well-developed emotional intelligence skills outperformed yearly revenue targets by 15 to 20 percent. Those with underdeveloped skills underperformed their targets by about the same amount (Goleman, Boyatzis, and McKee, 2002). Assessments of El dimensions have facilitated training and development modules for customer service skills, conflict management strategies, and stress management programs (Rozell, Pettijohn, and Parker, 2004). More importantly, high emotional intelligence partners contributed more than twice as much revenue to the company as did the low emotional intelligence partners (Boyatzis, 1982). Therefore, first hypothesis is,

Hypothesis 1: Emotional intelligence of managerial and non-managerial employees will expedite customer satisfaction.

\subsection{Recognition}

Recognition is believed to foster self-esteem and competence (Bartol and Srivastava, 2002), which provides powerful intrinsic motivation (Deci and Ryan, 2000). Employee recognition is a communication tool that reinforces and rewards the most important outcomes people create for business. When you recognize people effectively, you reinforce, with your chosen means of recognition, the actions and behaviors you want them to repeat. An effective employee recognition system is simple, immediate, and powerfully reinforcing. Research findings show that formal, informal and day-to-day recognition programs, when linked to the organizations values and goals, can create a culture of recognition that enhances employee engagement, performance and retention. Recognition is very much important for the organizational success, because a person wo- 
uld not like to give best effort unless he/she is recognized by others. It could be self-recognition or recognition from co-worker or from the superiors. It is also important to get recognition quickly to solve the problems in organization. It builds up primarily through communication between supervisors and subordinates.

Effective communications with employees, which is the basis for any internal communications effort, must start with how managers interact with other employees day to day (Argenti, 1998). Such interaction is an integral part of management and should be thought of not as an additional burden but as natural interactions with peers. What is the best approach for communicating with employees? Certainly it must begin with informal discussions between employees and supervisors. Employees must also feel secure enough in their positions to ask questions and offer advice without fear of reprisals from top management. By giving employees the respect they deserve and listening and interacting with them frequently, managers have the basis for an effective internal communications program. The task for the most senior managers, who have great pressures from both within and outside of the corporation, however, is much more difficult. From the above it is hypothesized that,

Hypothesis 2: Recognition of achievement and success of managerial and non-managerial employees will result in better relationships and in turn increases customer satisfaction.

\subsection{Active Listening}

Listening well has been found to distinguish the best managers, teachers, and leaders. Among those who are in the helping professions, like physicians or social workers, such deep listening numbers among the top three abilities of those whose work has been rated as outstanding by their organizations (Goleman, 2006). Active listening as Haas and Arnold (1995) found that in the workplace about one-third of the characteristics, people use to judge communication competence have to do with listening. Kramer (1997) found that good listening skills accounted for 40 percent of the variance in effective leadership. Supportive communication is the basic foundation to build a positive relationship. And this supportive communication requires the active listening most. Listening and responding effectively to someone else's statement is at least as important as delivering supportive messages (Whetten and Cameron, 2007). The ability to listen actively can improve personal re- lationships through reducing conflicts, strengthening cooperation, and fostering understanding. Active listening can increase the effectiveness of business and personal relationships. It is about listening for meaning and it is a way of listening to improve mutual understanding and improve overall communication. It is a listening skill that is used very effectively in stressful situations. Organizational cohesiveness is maintained by encouraging people to express their opinions, questioning rationally and giving them needed feedback. Active listening not only satisfies the employees but it also encourages them to perform better. Thus it can be hypothesized that,

Hypothesis 3: Actively listening to customers by managerial and non-managerial employees is positively related with customer satisfaction.

\subsection{Leadership}

To transform a company into a sustainable organization, in terms of both commitment and performance, leaders including top management have to approach in a way that engages the organization in a learning process. Good Leadership is frequently the explanation given for the success of almost any positive organizational relationship (Whetten and Cameron, 2007). These leaders connect authentically with people by being much more revealing. The second element of leadership is that the leaders have to have the will to essentially change and transform the company into integrated relationship. The next dimension of effective leadership is the willingness to inquire, to state boldly what they want, and what they think they need to do, and what the firm ought to be doing and to inquire from their own senior team, from the organization as a whole, from people at various levels in the organization (Beer, 2009). "You cannot be a true leader without connecting ... When you start thinking about it, leveraging the organization, it's all emotional." You have to capture the hearts and souls and minds of people. Then you can get their energy. A leader cannot be affective on his or her own, however: Personnel management practices must support, and not hinder, these efforts (Newman et al., 2009). People are rarely "energized" without some kind of an emotional commitment. For this to happen, the leader must trigger, stimulate, or evoke an emotional response on the part of potential followers so that those people will become engaged and active (Newman et al., 2009). The capacity to energize others through touching the emotions is the key to the art of leadership (Denhardt and Denhardt, 2006). Thus it is hypothesized that, 
Hypothesis 4: Leadership attributes of managerial and non-managerial employees are positively related with customer satisfaction.

\subsection{Teamwork}

Teamwork has emerged in recent years as one of the most important ways in which work is being reorganized (Osterman, 1994). Various arguments have been advanced to explain the effectiveness of team-based work. For example, both socio-technical theory (Pasmore, 1988) and work design theory (Hackman and Oldham, 1976) have focused on the design of the group's task to explain positive results; self-leadership theory has identified the supervisory behaviors that help self-managing teams achieve success (Manz and Sims, 1987); and theories of participative management argue that certain aspects of the organizational context contribute to the effectiveness of teams (Lawler, 1992). Strategic HRM theory, for example, suggests that an appropriately designed HR system, which typically includes teamwork, will have a positive effect on an employee's job satisfaction, commitment and motivation, leading to behavioral changes that result in improved organizational performance (Becker et al., 1997). Similarly, self-leadership theory focuses on participatory decision-making, individual discretion and teamwork as important motivating factors, and suggests these will lead to more committed employees who strive for greater efficiency and effectiveness (Sims and Manz, 1996).

A positive relationship between teamwork and operational performance is found in a number of studies. In the study of a textile manufacturer, Hamilton et al. (2003) found that team-sewing increased productivity by approximately $18 \%$. According to Cohen et al. (1996), a form of work organization incorporating teams and strong employee involvement had a significant impact on both quality and efficiency. Reducing the number of management layers, working with flexible job descriptions and the introduction of teamworking were all positively associated with different operational outcomes in the study of Bacon and Blyton (2000). Research on teams has consistently supported this view, as there is mounting evidence that collective efficacy is associated with team performance (Stajkovic, Lee, and Nyberg, 2009). Effective teams have independent members; members become more efficient working together than alone, they function so well that they create their own magnetism, they do not have the same leaders, and members care for each other and have trust among the members (Whetten and Cameron, 2007). Therefore, it is hypothesized that:

Hypothesis 5: Teamwork of managerial and nonmanagerial employees improves relationship at work that directly leads to higher customer satisfaction.

\subsection{Defensiveness}

Defensiveness is regarded as a coping style that is characterized by avoidance of threatening material and the minimization of negative affect (Paulhus and John, 1998). Kline et al. (1993) found that high defensive individuals registered emotional words, in particular sexual words, as indicated by their accurate detection, below the level of conscious awareness (when words were presented at lower durations). They argued that high defensive individuals were specifically sensitive to more subtle emotional information. It is commonsensical to assume that high defensive individuals are vigilant for threat-related material or emotional material at early stages of processing. This suggests that the initial motivation to inhibit threat stimuli is conscious but this can become automatic and no longer part of conscious awareness (Eisenberg, Cumberland, and Spinrad, 1998). If this is the case, it raises the question of whether high defensive individuals can generally suppress negative thoughts more effectively than low defensive individuals. Now two major obstacles of supportive communication that lead to variety of negative outcomes are defensiveness and disconfirmation (Cupach and Spitzberg, 1994). Defensive routines are the policies or actions we put in place to prevent ourselves and our organizations from experiencing embarrassment or threat. Organizational defensive routines are antilearning and overprotective. The "can do" attitude can blind people to seeing, and inhibit them from reporting and dealing with a potentially serious problem (Argyris, 1999). Disconfirmation bias is the tendency for people to scrutinize evidence that contradicts their previous beliefs and to uncritically accept evidence that supports it. It is useful because it helps us catch information that might result in altering our behavior and beliefs. When people are experienced with evidence for and against their beliefs, they will be more likely to accept the evidence that supports their beliefs with little scrutiny yet criticize and reject that which disconfirms their beliefs. We usually avoid or discount evidence that might show us to be wrong. It can be hypothesized that,

Hypothesis 6: Minimum attitude towards defensiveness by managerial and non-managerial employees will enhance customer satisfaction. 


\section{CONCEPTUAL MODEL}

In recent decades, the evolution of modern human resource management philosophy has been guided by the perception that employees are most satisfied and productive when they have some input and control over the work that they perform in the workplace (Morrow, 1997). This is certainly true of the "soft" variant approach of HRM (Marchington, 1995) or "normative theories" (Guest, 1997), which espouse active employee involvement in task and organization-related decisions and functions. Such an approach is characterized in practice by a quality driven philosophy where the focus is on effective organizational communications, consultative decision-making, teamwork, and employee development programs (Legge, 1995). It is too simplistic to sug- gest that organizations which are successful in times of great change and transition are paragons of explicit and transparent communications. Most research studies have an explicit or implicit theory, which describes, explains, predicts or controls the phenomenon under study. Theories are linked to conceptual models and frameworks; whereas a conceptual model is more abstract than a theory and a theory may be derived from a model, the framework is derived deductively from the theory (Burns and Groves, 2001). A model is tested that derived from a review of the literature by integrating theory and research relating to emotional intelligence, active listening, leadership, teamwork and friendship, recognition, defensiveness and their relationship with customer satisfaction.



Figure 1: Research Framework

\section{METHOD}

The study assumed two cohorts i.e., managerial employees (MEs) are those who are exempted from over time, committed to work extended hours and accomplish unassigned duties and responsibilities as required by the organization and non-managerial employees (NMEs) are those who are not exempted from over time. The sample consisted of 100 participants. Of them 75 were managerial employees and 25 were non-managerial employees. The small sample size is considered as because total number of employees was less than 150 in head office and most of them are managers. Moreover, the number of managerial employees was more than two-third of total employees and rest was non-managerial employees. The questionnaire was structured to carry out survey with employees of BBC's Dhaka office in Bangladesh. Initially the questionnaire was divided into seven (7) sections and designed to be scale rated. The items of each section were in the form of statements that were direct, simple and concise. The participants had to tick in the boxes provided beside each question according to the extent of their agreement (scale provided at the beginning of the questionnaire). Scale rating provided was: $1=$ 'Strongly Disagree', $2={ }^{\prime} \mathrm{Di}$ sagree', 3='Neutral', 4='Agree', 5='Strongly Agree'. Out of $75 \mathrm{MEs}, 28 \%$ were marketing executive, $24 \%$ were finance executive, $16 \%$ were communication executive, and 32\% were activation executive. The respondents' education level was primarily Bachelor of Business Administration (BBA) 5.3\%, Master of Business Administration (MBA) was $21.3 \%$, Master of Commer- 
ce (M.Com) was $41.3 \%$ and Master of Arts (MA) was $32 \%$. The length of work experience was between 5 to 6 years. Out of $75 \mathrm{MEs}$, male was $43(57.3 \%)$, and female was $32(42.7 \%)$ respectively. Some other demographic characteristics were position (Mean=2.5, $\mathrm{SD}=1.2$ ), education (Mean=6, $\mathrm{SD}=0.87$ ), tenure (Mean=1, SD=0), and gender (Mean=1.43, SD=0.49). Out of 25 NMEs, $40 \%$ were senior reporter, $28 \%$ were staff reporter, and $32 \%$ were photographer. The level of education was Bachelor of Arts (BA) in English was $28 \%$, BA in Public Administration was $40 \%$, and BA in Journalism was $32 \%$. The length of services e.g., 1 to 2 years was $72 \%$, and 3 to 4 years was $28 \%$. Of the total NMEs, male was 17 (68\%), and female was 8 (32\%) respectively. Other demographic characteristics were position (Mean $=5.9, S D=0.86$ ), education (Mean=2, $\mathrm{SD}=0.79$ ), tenure (Mean=2.3, $\mathrm{SD}=0.46$ ), and gender (Mean=1.3, SD=0.47). Data gained were analyzed with SPSS for Windows 11.5. Cronbach's alpha was calculated to know the reliability. In order to test the hypotheses the analyses of Pearson Correlation and linear regression were used. Data were analyzed using descriptive statistics to project the respondents' profiles as well as the general patterns of the variations in supportive communication affecting customer satisfaction.

\section{ANALYSIS AND RESULTS}

Table 1 below represents Cronbach's alpha (a) ranges from 0.78 to 0.99 , which was required to know internal consistency of the items used within the variables with regard to managerial (MEs) and non-managerial employees (NMEs). This measure demonstrated adequate reliability values $(a>.7)$ and acceptable for further analysis (George and Mallery, 2003).

Table 1: Reliability Values Alpha (a) of the Employees in The Study

\begin{tabular}{|l|c|c|}
\hline \multicolumn{1}{|c|}{ Variables } & Cronbach & Alpha \\
\hline & MEs & NMEs \\
\hline Emotional Intelligence & .85 & .82 \\
\hline Recognition & .87 & .84 \\
\hline Active Listening & .83 & .87 \\
\hline Leadership & .91 & .92 \\
\hline Teamwork & .85 & .86 \\
\hline Defensiveness & .99 & .90 \\
\hline Customer Satisfaction & .88 & .78 \\
\hline
\end{tabular}

Descriptive statistics and correlation coefficient values of all the constructs are displayed in Table 2 and Table 3. Mean scores have been figured out by equally weighting the mean scores of all the items.
With regard to MEs and NMEs (Table 2 and Table 3) the mean scores of customer satisfaction is 4.31 and 3.50 respectively which indicate that MEs are more satisfied with their job than NMEs. The mean values of emotional intelligence for either cohort are 3.82 and 3.71 respectively which denote that emotional intelligence is more important to managers than non-managers. Likewise, mean score of recognition is 4.67 with regard to non-managerial employees which is higher than managerial employee's mean value of 3.83 . This clearly indicates that tangible and intangible recognitions being offered by managers could play a substantial role to satisfy nonmanagerial employees. Correspondingly, active listening, leadership and teamwork secured higher mean values with regard to managerial employees. The mean value of defensiveness is 3.92 and 3.42 with regard to managerial and non-managerial employees respectively that imply managers make all out efforts to hold back organization from any potential threat related to supportive communication that later on might put it into embarrassing situation than that of non-managers.

Hypothesis 1 stated that emotional intelligence of managerial and non-managerial employees will expedite customer satisfaction. The study found that $\mathrm{El}$ is positively related with customer satisfaction (Table 2 and Table 3 ) with regard to MEs ( $r=.81^{* *}$, $\mathrm{p}<.01$ ) but customer satisfaction is negatively related with El with regard to NMEs. Hypothesis 1 is accepted for MEs but rejected in case of NMEs. Regression results in Table 4 also supported the hypothesis only in case of MEs $\left(\beta=.87^{*}, p<.05\right)$ but for NMEs it indicated negative relationship $\left(\beta=-.04^{*}, p<.05\right)$.

Hypothesis 2 stated that recognition of achievement and success of managerial and non-managerial employees will result in better relationships and in turn increases customer satisfaction. The study found that recognition is positively related with customer satisfaction (Table 2 and Table 3 ) only in case of MEs $\left(r=.65^{* *}, p<.01\right)$. Hence, hypothesis is accepted. Regression results in Table 4 also supported the hypothesis with regard to MEs $\left(\beta=.61^{*}, p<.05\right)$ but in case of NMEs it indicated weak relationship $\left(\beta=.03^{*}\right.$, $\mathrm{p}<.05)$.

Hypothesis 3 stated that active listening to customers by managerial and non-managerial employees is positively related with customer satisfaction. The study found (Table 2 and Table 3 ) that active listening is positively related with customer satisfaction both in case of MEs $\left(r=.84^{* *}, p<.01\right)$ and NMEs 
Table 2: Means, Standard Deviations, and Correlations of MEs

\begin{tabular}{|l|c|c|c|c|c|c|c|c|c|}
\hline \multicolumn{1}{|c|}{ Variables } & Mean & SD & 1 & 2 & 3 & 4 & 5 & 6 & 7 \\
\hline 1. Emotional Intelligence & 3.82 & .44 & & & & & & & \\
\hline 2. Recognition & 3.83 & .47 & $.75^{* *}$ & & & & & & \\
\hline 3. Active Listening & 3.83 & .41 & $.86^{* *}$ & $.74^{* *}$ & & & & & \\
\hline 4. Leadership & 3.83 & .45 & $.84^{* *}$ & $.73^{* *}$ & $.86^{* *}$ & & & & \\
\hline 5. Teamwork & 3.88 & .43 & $.77^{* *}$ & $.78^{* *}$ & $.76^{* *}$ & $.77^{* *}$ & & & \\
\hline 6. Defensiveness & 3.92 & .43 & -.22 & -.05 & -.20 & -.21 & -.04 & & \\
\hline 7. Customer Satisfaction & 4.31 & .73 & $.81^{* *}$ & $.65^{* *}$ & $.84^{* *}$ & $.81^{* *}$ & $.74^{* *}$ & -.18 & \\
\hline
\end{tabular}

Table 3: Means, Standard Deviations, and Correlations of Variables of NMEs

\begin{tabular}{|l|c|c|c|c|c|c|c|c|c|}
\hline \multicolumn{1}{|c|}{ Variables } & Mean & SD & 1 & 2 & 3 & 4 & 5 & 6 & 7 \\
\hline 1. Emotional Intelligence & 3.71 & .85 & & & & & & & \\
\hline 2. Recognition & 4.67 & .42 & .14 & & & & & & \\
\hline 3. Active Listening & 3.56 & .78 & .04 & -.02 & & & & & \\
\hline 4. Leadership & 3.36 & .47 & .38 & .06 & -.15 & & & & \\
\hline 5. Teamwork & 3.35 & .43 & .36 & .14 & .03 & $.66^{* *}$ & & & \\
\hline 6. Defensiveness & 3.42 & .44 & $.41^{*}$ & .26 & 0 & $.69^{* *}$ & $.75^{* *}$ & & \\
\hline 7. Customer Satisfaction & 3.50 & .77 & -.05 & .06 & $.9^{* *}$ & -.13 & .03 & .14 & \\
\hline
\end{tabular}

$\mathrm{N}=25 ; * * \mathrm{p}<.01,{ }^{*} \mathrm{p}<.05$

$\left(r=.9^{* *}, p<.01\right)$. Thus hypothesis is accepted. Regression results in Table 4 also supported the hypothesis with regard to MEs $\left(\beta=.86^{*}, p<.05\right)$ and NMEs $\left(\beta=.89^{*}, p<.05\right)$.

Hypothesis 4 stated that leadership attributes of managerial and non-managerial employees are positively related with customer satisfaction. The research reported that leadership is positively related (Table 2 and Table 3 ) with customer satisfaction $\left(r=.81^{* *}, p<.01\right)$ in case of MEs but in case of NMEs it found no relationship. As such hypothesis is accepted with regard to MEs. Regression results in Table 4 also supported the hypothesis with regard to MEs $\left(\beta=.79^{*}, p<.05\right)$ but in case of NMEs it found reverse relationship $\left(\beta=-.21^{*}, p<.05\right)$.

Table 4: Regression Results Of Supportive Communication Affecting MEs and NMEs

\begin{tabular}{|c|c|c|c|c|c|c|c|c|}
\hline \multirow[t]{2}{*}{ Variables } & \multicolumn{4}{|c|}{ Manager } & \multicolumn{4}{|c|}{ Non-Manager } \\
\hline & $\beta$ & $\mathrm{T}$ & $\mathrm{F}$ & $A R^{2}$ & $\beta$ & $\mathrm{T}$ & $\mathrm{F}$ & $A R^{2}$ \\
\hline Emotional Intelligence & .87 & 11.6 & 135 & .64 & -.04 & -.23 & .05 & .04 \\
\hline Recognition & .61 & 7.4 & 55 & .42 & .03 & .07 & .01 & .04 \\
\hline Active Listening & .86 & 13.3 & 178 & .71 & .89 & 9.5 & 91 & .80 \\
\hline Leadership & .79 & 11.8 & 139 & .65 & -.21 & -.61 & .36 & .03 \\
\hline Teamwork & .77 & 9.4 & 90 & .54 & .04 & .12 & .01 & .04 \\
\hline Defensiveness & -.11 & -.15 & 2.4 & .02 & -.24 & -.65 & .43 & .02 \\
\hline
\end{tabular}

$\mathrm{N}=100 ;{ }^{*} \mathrm{p}<.05$

Hypothesis 5 stated that teamwork by managerial and non-managerial employees will improve customer relationship at work that directly leads to higher customer satisfaction. The study indicated that teamwork is positively related (Table 2 and Table 3 ) with customer satisfaction in case of MEs $\left(r=.74^{* *}, p<.01\right)$ but with regard to NMEs no relationship was observed. Thus hypothesis is accepted in case of MEs but rejected in case of NMEs. Regression results in Table 4 also supported the hypothesis with regard to MEs $\left(\beta=.77^{*}, p<.05\right)$ but in case of NMEs weak relationship was observed $\left(\beta=.04^{*}, p<.05\right)$.

Hypothesis 6 stated that minimum attitude towards defensiveness by managerial and nonmanagerial employees will enhance customer satisfaction. The study found that defensiveness has no 
significant relationship with customer satisfaction (Table 2 and Table 3) both in case of managerial and non-managerial employees. Thus hypothesis is accepted. Regression results in Table 4 also supported hypothesis both in case of MEs $\left(\beta=-.11^{*}, p<.05\right)$ and NMEs $\left(\beta=-.24^{*}, p<.05\right)$. It was found from regression analyses (Table 4 ) that all determinants of supportive communication significantly affect customer satisfaction with regard to managerial employees but for non-managerial employees only active listening affects the customer satisfaction. The study also found highest value of adjusted $\mathrm{R} 2$ with regard to managerial employees as 0.71 and in case of non-managerial employees as 0.8 also indicates that the variables are related significantly.

\section{DISCUSSION}

The study found significant positive relationship of the variables with customer satisfaction (Table 2) with regard to managerial employees. This means that managers are proactive to ensure customer satisfaction in the first place than non-managers. The significant relationship was also observed in regression results (Table 4). In contrast, only the active listening has been found significantly related (Table 3) with customer satisfaction with regard to nonmanagerial employees. The study indicated significant positive relationship of emotional intelligence with customer satisfaction. Previous research has suggested that emotions play an important role in service encounters (Menon and Dube, 2000) and that the display of emotions by service employees influences customers' affect and judgment of service quality (Pugh, 2001). According to him, the reciprocal nature of service encounters produces an emotional contagion effect whereby customers 'catch' the emotions displayed by the customer service agent. In a study of service providers working in fast food outlets in Singapore (Tan et al., 2004) the display of positive emotions by service providers was also linked with customer satisfaction. Both studies also found that transaction or store busyness had a moderating influence on customer satisfaction. While interacting with members of the social environment, emotionally intelligent people produce win-win relationships and outcomes for themselves and for others. Such people develop a magnetic field of emotional attraction around them and often are the owners of an ever-increasing network of social relationships and emotional support structures (Kunnanatt, 2004). The study also noted that emotional competence was associated with employee's positive feelings which in turn were related to the customers' positive feedback. The finding may suggest that one important way to regulate the customers' positive effect requires the employees to first regulate their own emotion, which then spills over to the customer (Giardini and Frese, 2008).

The research also observed that recognition, and rewards are essential to have supportive communication and to leverage customer satisfaction. Recognition is believed to foster self-esteem and competence (Bartol and Srivastava, 2002) which provides powerful intrinsic motivation (Deci and Ryan, 2000). The influence of non-financial rewards draws (e.g., recognition) on the social exchange perspective (Blau, 1964). When employees perceive that their needs are being accommodated (e.g. alternative work arrangements) or that an organization is willing to invest in them (e.g. training and development), they are more likely to reciprocate with improved performance. Positive performance may even reside outside formal duties to benefit their organization in other ways (Organ and Ryan, 1995) such as reciprocating with pro-social and extra-role citizenship behavior (Podsakoff et al., 2000). Here, the employment relationship is relational and characterized by long-term and socio-emotional elements of an employment exchange (Rousseau, 2004). Non-financial rewards tend to have a broader latitude and longerterm focus in terms of performance (Kalleberg and Rognes, 2000).

The study identified the importance of active listening in supportive communication while keeping the customers satisfied. Mineyama et al. (2007) used the active listening attitude scale to measure the effect of listening on employees' perceptions of working conditions and psychological stress. The active empathetic listening scale presented by Drollinger et al. (2006) was used to assess the effectiveness of listening in relation to business sales and customer satisfaction. Research on leader-member exchange (LMX) consistently shows that a manager's history and present relationship with individual employees influences perception of trust, communication, openness, and empowerment (Dansereau, Graen, and Haga, 1975).

The research indicated leadership traits of employees are ally for supportive communication as well as better customer satisfaction. Anderson and Huang (2006) reported that employees who have some control over the interaction with customers when delivering services are better able and more willing to satisfy customers' needs. It is also noted that cus- 
tomers tend to be more satisfied when service employees respond to their special needs and desires. Leaders are responsible for "communicating to the organization the risks in clinging to the status quo and the potential rewards of embracing a radically different future" (Denning, 2005). Leadership ambivalence weakens claims of legitimacy for change and enables recipients to cling to reasons for resistance (Larson and Tompkins, 2005). Consequently, communications should be frequent and enthusiastic (Lewis, Schmisseur, Stephens and Weir, 2006), while leaders simultaneously curb their bias toward unrealistic optimism (Lovallo and Kahneman, 2003). Disappointing or unfavorable results due to unfulfilled or inaccurate promises and predictions undermine leadership credibility and lead to employee perceptions of injustice, misrepresentation, and violations of trust (Tomlinson, Dineen and Lewicki, 2004).

Teamwork culture being practiced by the employees was supportive for increased level of customer satisfaction. Previous research findings supported this relationship. For example Strategic HRM theory suggests that an appropriately designed HR system, which typically includes teamwork, will have a positive effect on an employee's job satisfaction, commitment and motivation, leading to behavioral changes that result in improved organizational performance (Becker et al., 1997). Similarly, self-leadership theory focuses on participatory decision-making, individual discretion and teamwork as important motivating factors, and suggests these will lead to more committed employees who strive for greater efficiency and effectiveness (Sims and Manz, 1996). The synergistic benefits of teamwork enable members working cooperatively with one another to achieve more than by working independently (Trent, 2004). Recent studies have reported an ever-increasing number of firms using teams to accomplish organizational tasks in response to serious challenges posed by a dynamic global economy (Oh, Chung and Labiance, 2004; Towry, 2003). Effectively managing teams and structuring work groups in ways that support collaboration are two leadership abilities necessary for achieving organizational goals.

The study found that customer satisfaction decreased with increased level of defensiveness stemmed from employees. Less defensive personality attributes internally are benign for supportive communication and would result better customer satisfaction. Similar study was reported by several authors (Barger, Kircher and Croyle, 1997; Derakshan and Eysenck, 2001a; Myers, 2000) that high defensive individuals (and in particular repressors) under high stress conditions showed high levels of autonomic reactivity while reporting low levels of anxiety and negative affect. Such discrepancies have been widely investigated in the literature and have been reliably found in many populations using various physiological and behavioral measures.

\section{CONCLUSION}

It can be concluded that the significant impact of customer satisfaction is caused by active listening with high correlation for both managerial and nonmanagerial employees. Both cohorts emphasize the importance of active listening to create smoother flow of information and to minimize discrepancies leading to better coordination and understanding to provide higher customer service. On the other hand, the degree of defensiveness for management has the least correlation with customer service. Additionally, for both managerial and non-managerial employees such attitude has no effect on customer satisfaction. While there is evidence of no effect of leadership on customer satisfaction with regard to non-managerial employees but quest of leadership for supportive communication was underscored by managers. In conclusion, manager's beliefs and practices are more aligned with theoretical views while non-managers still have a long way to go in establishing the relation between effective and supportive tools of communications and its effect on relationship building. The sample size was not large $(\mathrm{N}=100)$. Small sample size generates low statistical power and generalizability. It is highly commended that applying large sample size both in service and manufacturing industries might produce significant outcome on tangible role of supportive communication across organizations. Managers require getting out from behind their desks, putting down their telephones, getting away from their computers, and going out and getting to know the people who are working for them. No other method works as well, and no quick fix will satisfy the basic need for interaction with other people. With all of the sophisticated technology available to communicate with employees today such as electronic mail, newsgroups, desktop publishing, and satellite meetings to far-flung places, the most important factor in internal communications begins with the manager who has a responsibility to his/her employees. That responsibility is to listen to what they have to say and to get to know who they really are as human beings. Today's employees want more high tech and sophisticated communications, but they also want more human interaction than ever before. Understanding that fact is the key to an effective employee supportive communication program for any organizations. 


\section{END NOTES}

An earlier version of the paper was presented in $11^{\text {th }}$ South Asian Management Forum (www.amdisa.org) in Nepal from May 16-18, 2011 and jointly organized by Nepal Administrative Staff College (NASC), Katmandu, Nepal with Association of Management Development Institutions in South Asia (AMDISA).

\section{REFERENCES}

Anderson R.E. ve Huang W. (2006) "Empowering Salespeople:Personal, Managerial, and Organizational Perspectives" Psychol Market, 23(2):139-160.

Argenti, P.A. (1998) "Strategic Employee Communications" Human Resource Management, 37(3/4):199-206.

Argyris, C. (1999) On Organizational Learning, 2nd Edition, Malden, MA, Blackwell Publishers.

Bacon, N. ve Blyton, P. (2000) "High Road and Low Road Teamworking: Perceptions of Management Rationales and Organizational and Human Resource Outcomes" Human Relations, 53:1425-1458.

Baker, W. (2000) Achieving Success Through Social Capital, San Francisco, Jossey-Bass.

Barger, S.D., Kircher, J.C. ve Croyle, R.T. (1997) "The Effects of Social Context and Defensiveness on the Physiological Responses of Repressive Copers" Journal of Personality and Social Psychology, 73:1118-1128.

Barlow, J. ve Maul, D. (2000) Emotional Value:Creating Strong Bonds with your Customers, San Francisco, CA, Berrett-Koehler.

Bartol, K.M. ve Srivastava, A. (2002) "Encouraging Knowledge Sharing: The Role of Organizational Reward Systems" Journal of Leadership and Organization Studies, 9:64-76.

Batt, R. (2002) "Managing Customer Services: Human Resource Practices, Quit Rates and Sales Growth” Academy of Management Journal, 45(3):587597.

Batt, R. ve Moynihan, L. (2004) "The Viability Of Alternative Call Centre Production Models" Deery et al (eds.) Call Centres and Human Resource Management: A Cross-National Perspective, Basingstoke, Palgrave Macmillan.

Becker, B.E., Huselid, M.A., Pickus, P.S. ve Spratt, M.F. (1997) "HR as A Source of Hareholder Value: Research and Recommendations" Human Resource Management, 36(1):39-47.

Beer, M. (2009) High Commitment, High Performance: How to Build a Resilient Organization for Sustained Advantage, San Francisco, Jossey-Bass.
Bitner, M.J., Booms, B.H. ve Mohr, L.A. (1994) "Critical Service Encounters: The Employee's Viewpoint" The Journal of Marketing, 58(4):95-106.

Blau, T. (1964) Exchange and Power in Social Life, New York, Wiley.

Bloom, B.L., White, S.W. ve Asher, S.J. (1979) Marital Disruption As A Stressful Life Event. Levinger et al(eds.) Divorce and Separation: Context, Causes and Consequences, New York, Basic Books.

Boyatzis, R.E. (1982) "The Competent Manager: A Model for Effective Performance" New York, Wiley.

Brackett, M.A., Rivers, S.E., Shiffman, S., Lerber, N. ve Salovey, P. (2006) "Relating Emotional Abilities to Social Functioning: A Comparison of Self-Report and Performance Measures of Emotional Intelligence" Journal of Personality and Social Psychology, 91:780-795.

Buckley, F., Monks, K. ve Sinnott, A. (1998) "Communication Enhancement: A Process Dividend for the Organization and the HRM Department?" Human Resource Management, 37(3/4):221-234.

Burns, N. ve Groves, S. (2001) The Practice of Nursing Research, Conduct, Critique\& Utilization, 4th Edition, Toronto, Ontario, W.B Saunders Company.

Cacioppo, J.T., Hawkley, L.C. ve Bernston, G.G. (2003) "The Anatomy of Loneliness" Current Directions in Psychological Science, 12:71-74.

Cohen, S.G., Ledford, G.E. ve Spreitzer, G.M. (1996) "A Predictive Model of Self-Managing Work Team Effectiveness" Human Relations, 49:643-676.

Cupach, W.R. ve Spitzberg, B.H. (1994) The Dark Side of Interpersonal Communications, Hillsdale, N.J, Lawrence Erlbaum.

Dansereau, F.J, Graen, G. ve Haga, W.J. (1975) "A Vertical Dyad Linkage Approach to Leadership Within Formal Organizations: A Longitudinal Investigation of the Role Making Process" Organizational Behavior and Human Performance, 13:46-78.

Deci, E.L. ve Ryan, R.M. (2000) "The What and Why of Goal Pursuits: Human Needs and the SelfDetermination of Behavior" Psychological Inquiry, 11:227-268. 
Denhardt, R.B. ve Denhardt, J.V. (2006) The Dance of Leadership: The Art of Leading in Business, Government, and Society" Armonk, NY, Sharpe.

Denning, S. (2005) "Transformational Innovation" Strategy and Leadership, 33(3):11-16.

Derakshan, N. ve Eysenck, M.W. (2001a) "Manipulation of Focus of Attention and Its Effects on Anxiety in High-Anxious Individuals and Repressors" Anxiety, Stress, and Coping, 14:173-191.

Drollinger, T.L., Comer. L.B. ve Warrington, P.T. (2006) "Development and Validation of the Active Empathetic Listening Scale" Psychology\&Marketing, 23(2):161-180.

Dutton, J.E. (2003) Energize Your Workplace: How To Create And Sustain High Quality Relationships At Work, San Francisco, Jossey-Bass.

Eisenberg, N., Cumberland, A. ve Spinrad, T.L. (1998) "Parental Socialization of Emotion" Psychological Inquirer, 9:241-273.

Fredrickson, B.L. (2001) "The Role of Positive Emotions in Positive Psychology: The BroadenAnd-Build Theory of Positive Emotions" American Psychologists, 56:218-226.

George, D. ve Mallery, P. (2003) SPSS for Windows Step by Step: A Simple Guide and Reference. 11.0 Update, 4th Edition, Boston, Allyn \& Bacon.

Giardini, A. ve Frese, M. (2008) "Linking Service Employees' Emotional Competence to Customer Satisfaction: A Multilevel Approach" Journal of Organizational Behavior, 29(2):155-170.

Gittell, J.H., Cameron, K.S. ve Lim, S. (2006) "Relationships, Layoffs, and Organizational Resilience: Airline Industry Responses to September 11th Journal of Applied Behavioral Science, 42:300-329.

Goleman, D. (2006) Social Intelligence: Th $e$ NewScience of Human Relationships, New York, Bantam Publications.

Goleman, D., Boyatzis, R. ve McKee, A. (2002) Primal Leadership: Realizing the Power of Emotional Intelligence, Boston, Harvard Business School Press.

Guest, D. (1997) "Human Resource Management and Performance: A Review and Research Agenda" The International Journal of Human Resource Management, 8(3):263-276.

Hackman, J.R. ve Oldham, G.R. (1976) "Motivation Through The Design of Work: Test of A Theory" Organizational Behaviour and Human Performance, 16:250-279.
Haas, J.W. ve Arnold, C.L. (1995) "An Examination of the Role Listening in Judgments of the Communication Competence in Coworkers" Journal of Business Communication, 32:123-139.

Hamilton, B.H., Nickerson, J.A. ve Owan, H. (2003) "Team Incentives and Worker Heterogeneity: An Empirical Analysis of the Impact of Teams on Productivity and Participation" Journal of Political Economy, 111:465-497.

Hanson, G. (1986) Determinants of Firm Performance: An Integration of Economic and Organizational Factors, Unpublished Doctoral Dissertation, University of Michigan Business School.

Heath, R.L. ve Bryant, J. (1992) Human Communication Theory and Research: Concepts, Contexts, and Challenges, Hillsdale, N.J, Lawrence Erlbaum.

Hurley, J. (1990) "The Collaborative Imperative of New Technology" The Irish Journal of Psychology, 11(2):211-220.

Kalleberg, A.L. ve Rognes, J. (2000) "Employment Relations in Norway: Some Dimensions and Correlates" Journal of Organizational Behavior, 21:315-335.

Kline, J.P., Schwartz, G.E., Fitzpatrick, D.F. ve Hendricks, S.E. (1993) "Defensiveness, Anxiety and The Amplitude/Intensity Function of Auditory-Evoked Potentials" International Journal of Psychophysiology, 15:7-14.

Koys, D.J. (2001) "The Effects of Employee Satisfaction, Organizational Citizenship Behavior, and Turnover on Organizational Effectiveness: A Unit-Level, Longitudinal Study" Personnel Psychology, 54(1):101114.

Kramer, R. (1997) "Leading By Listening: An Empirical Test of Carl Roger's Theory of Human Relationship Using Interpersonal Assessment of Leaders by Followers" Unpublished Doctoral Dissertation, George Washington University.

Kunnanatt, J.T. (2004) "Emotional Intelligence: The New Science of Interpersonal Effectiveness" Human Resource Development Quarterly, 15(4):489-495.

Larson, G.S. ve Tompkins, P.K. (2005) "Ambivalence and Resistance: A Study of Management in A Concertive Control System" Communication Monographs, 72:1-21.

Lawler, E.E. (1992) The Ultimate Advantage: Creating the High Involvement Organization, San Francisco, CA, Jossey-Bass. 
Leary, M.R. (1990) "Responses to Social Exclusion: Social Anxiety, Jealousy, Loneliness, Depression, and Low Self-Esteem" Journal of Social and Clinical Psychology, 9:221-229.

Leban, W. ve Zulauf, C. (2004) Linking Emotional Intelligence Abilities and Transformational Leadership Styles" The Leadership \& Organization Development Journal, 25(7):554-564.

Legge, K. (1995) Human Resource Management Rhetoric and Realities, London, MacMillan.

Lewis, L.K., Schmisseur, A.M., Stephens, K.K. ve Weir, K.E. (2006) "Advice on Communicating During Organizational Change" Journal of Business Communications, 43:113-137.

Liao, H. ve Chuang, A. (2004) "A Multilevel Investigation of Factors Influencing Employee Service Performance and Customer Outcomes" Academy of Management Journal, 47(1):41-58.

Lopes, P.N., Salovey, P. ve Straus, R. (2003) "Emotional Intelligence, Personality and the Perceived Quality of Social Relationship" Personality and Individual Differences, 35:641-658.

Lovallo, D. ve Kahneman, D. (2003) "Delusions of Success: How Optimism Undermines Executive Decisions" Harvard Business Review, 81(7):56-63.

Manz, C.C. ve Sims, H.P. (1987) "Leading Workers to Lead Themselves: The External Leadership of SelfManaging Work Teams" Administrative Science Quarterly, 32:106-128.

Marchington, M. (1995) "Involvement and Participation" Storey, J. (eds.) Human Resource Management: A Critical Text, London, Routledge.

Menon, K. ve Dube, L. (2000) "Ensuring Greater Satisfaction by Engineering Salesperson Response to Customer Emotions" Journal of Retailing, 76(3):285-302.

Mineyama, S., Tsutsumi, A., Soshi, T., Nishiguchi, K. ve Kawakami, N. (2007) "Supervisor's Attitudes and Skills for Active Listening With Regard to Working Conditions and Psychological Stress Reactions Among Subordinate Workers" Journal of Occupational Health 49:81-87.

Morrow, P.C. (1997) "The Measurement of TQM Principles and Work-Related Outcomes" Journal of Organizational Behavior, 18(4):363-376.

Mueller, J.S. ve Curhan, J.R. (2006) "Emotional Intelligence and Counterpart Affect Induction in A Negotiation" International Journal of Conflict Management ,17:110-128.
Myers, L.B. (2000) "Identifying Repressors: A Methodological Issue for Health Psychology" Psychology and Health, 15:205-214.

Newman, M.A., Guy, M.E. ve Mastracci, S.H. (2009) "Beyond Cognition: Affective Leadership and Emotional Labor" Public Administration Review, 69(1):620.

Oh, H., Chung, M.H. ve Labianca, G. (2004) "Group Social Capital and Group Effectiveness: The Role of Informal Socializing Ties" Academy of Management Review, 47:860-875.

Organ, D.W. ve Ryan, K. (1995) "A Meta-Analytic Review of Attitudinal and Dispositional Predictors of Organizational Citizenship Behaviors" Personnel Psychology, 48:775-802.

Osterman, P. (1994) "How Common is Workplace Transformation and Who Adopts It?" Industrial and Labor Relations Review, 47:173-188.

Pasmore, W.A. (1988) Designing Effective Organizations: the Sociotechnical Systems Perspective, New York, Wiley.

Paulhus, D.L. ve John, O.P. (1998) "Egoistic and Moralistic Bias in Self-Perception: The Interplay of SelfDeceptive Styles With Basic Traits And Motives" Journal of Personality, 66: 1025-1060.

Pfeffer, J. (1998) The Human Equation: Building Profits By Putting People First, Boston, Harvard Business School Press.

Podsakoff, P.M., MacKenzie, S.B., Paine, J.B. ve Bachrach, D.G. (2000) "Organizational Citizenship Behaviors: A Critical Review of the Theoretical and Empirical Literature and Suggestions for Future Research" Journal of Management, 26:513-63.

Pugh, S.D. (2001) "Service With A Smile: Emotional Contagion in the Service Encounter" Academy of Management Journal, 44(5):1018-1028.

Rousseau, D.M. (2004) "Psychological Contracts in The Workplace: Understanding The Ties That Motivate" Academy of Management Executive, 18:120-127.

Rozell, E., Pettijohn, C. ve Parker, R. (2004) "Customer-Oriented Selling: Exploring The Roles of Emotional Intelligence and Organizational Commitment" Psychology and Marketing, 21:405-424.

Schneider, B., White, S.S. ve Paul, M.C. (1998) "Linking Service Climate and Customer Perceptions of Service Quality: Test of A Causal Model” Journal of Applied Psychology, 88(2): 150-163. 
Schopenhauer, A. (1964) The Pessimist's Handbook, Lincoln, University of Nebraska Press.

Sims, H. ve Manz, C. (1996) "Company of Heroes:Unleashing the Power of Self-Leadership" New York, Wiley.

Slaski, M. ve Cartwright, S. (2002) "Health, Performance and Emotional Intelligence" Stress and Health, 18:63-69.

Spector, P.E., Dwyer, D.J. ve Jex, S.M. (1988) "Relaxation of Job Stressors of Affective Health and Performance Outcomes: A Comparison of Multiple Data Sources" Journal of Applied Psychology, 73:11-18.

Stajkovic, A.D., Lee, D. ve Nyberg, A.J. (2009) "Collective Efficacy, Group Potency, and Group Performance: Meta-Analysis of Their Relationships, and Test of A Mediation Model" Journal of Applied Psychology, 94:814-828.
Tan, H.H., Foo, M.D. ve Kwek, M.H. (2004) "The Effects of Customer Personality Traits on The Display of Positive Emotions" Academy of Management Journal, 47(2):287-296.

Tomlinson, E.C., Dineen, B.R. ve Lewicki, R.J. (2004) "The Road to Reconciliation: Antecedents of Victim Willingness to Reconcile Following A Broken Promise" Journal of Management, 30:165-187.

Towry, K.L. (2003) "Control in A Teamwork Environment: The Impact of Social Ties on the Effectiveness of Mutual Monitoring Contracts" Accounting Review, 78:1069-1096.

Trent, R. J. (2004) "Becoming An Effective Teaming Organization” Business Horizons, 47:33-41.

Whetten, D.A. ve Cameron, K.S. (2007) Developing Management Skills, 7th Edition, New Jersey, Pearson Prentice Hall. 